\title{
JEJAK-JEJAK BENCANA SOSIAL PADA PROSES KONVERSI RELIGI- POLITIK MASA KLASIK AWAL (ABAD 5-7) DI ASIA TENGGARA
}

\author{
Traces of Social Disasters During Religion-Political Conversion in Early Classic Period $\left(5^{\text {th }}\right.$ - \\ $7^{\text {th }}$ Centuries) in Southeast Asia
}

Nainunis Aulia Izza

Program Studi Arkeologi, Universitas Jambi

Jalan Jambi-Muara Bulian Km. 15, Mendalo Indah, Kabupaten Muaro Jambi

E-mail: nainunis@unja.ac.id

\begin{abstract}
Religion and political conversion took place in the early classical period in Southeast Asia. This process happened around 5th -7th, when Hinduism and Buddhism began to replace Vedic. Initial indications shows that religion and political conversion occurred almost at the same time raises problems related to the factors and the methods during the conversion process. This study discussed religion and political conversion based on study literature method. The areas discussed in this study include Java, Kalimantan, Sumatra, and mainland Southeast Asia. Archaeological and epigraphical evidences show that the factors of this conversion based on religious and economic factors. The religious factor had strong relation with the development of Hinduism and Buddhism. Hinduism and Buddhism led to the emergence of new rulers. The new rulers felt they must conquer areas which controlled by Vedic rulers. The Conquest was motivated by economic factors, the struggle for conquest trade centre and sources of commodities became the basis for conflicts. Archaeological dan epigraphical data shows similar conquest pattern around Southeast Asia. The mission to change the religion and economic ambition raises a social disaster manifested in war and destruction.
\end{abstract}

Keywords: political, religion, social disaster, Southeast Asia ,Vedic.

\begin{abstract}
Abstrak
Proses konversi religi dan politik pernah terjadi di Asia Tenggara masa klasik awal. Peristiwa ini berlangsung sekitar kurun abad ke-5 sampai dengan ke-7 Masehi, ketika Agama HinduBuddha mulai menggantikan Agama Weda. Adanya indikasi proses konversi religi dan politik pada kurun waktu yang hampir bersamaan memunculkan masalah mengenai faktor-faktor yang melatarinya serta cara-cara konversi yang dilakukan. Tulisan ini merupakan hasil kajian yang dilakukan melalui studi kepustakaan terhadap berbagai hasil penelitian yang membahas tentang bukti-bukti proses konversi religi dan politik. Wilayah-wilayah yang dibahas pada tulisan ini antara lain adalah Jawa, Kalimantan, Sumatra, dan Daratan Utama Asia Tenggara. Hasilnya, berdasarkan data-data arkeologis dan epigrafis menunjukkan faktor pendorongnya adalah religi dan ekonomi. Faktor religi dapat dikaitkan dengan perkembangan Agama Hindu-Buddha di India yang mengantikan Agama Weda. Agama Hindu-Buddha mendorong munculnya penguasa-penguasa baru. Penguasa-penguasa baru tersebut merasa berhak menaklukkan berbagai wilayah yang sebelumnya dikuasai pemimpin yang menganut Weda. Dorongan penaklukan diperkuat dengan faktor ekonomi, yaitu usaha merebut berbagai pusat dagang dan sumber komoditi dagang yang selanjutnya menjadi dasar terjadi konflik. Pola penalukan yang didasarkan data arkeologi dan epigrafi pada berbagai wilayah di Asia Tenggara menunjukkan pola yang hampir sama. Misi untuk mengubah aspek religi dan ambisi ekonomi memunculkan bencana sosial berupa perang dan penghancuran.
\end{abstract}

Kata kunci: politik, religi, bencana sosial, Asia Tenggara, Weda. 


\section{PENDAHULUAN}

Memasuki abad masehi, berbagai wilayah di Asia Tenggara mendapat pengaruh India yang disebut dengan Indianisasi. Proses Indianisasi ini berlangsung akibat kontak antara masyarakat Asia Tenggara dengan bangsa-bangsa yang berasal dari wilayah Asia Selatan yang menyebabkan unsur-unsur kebudayaan dari India ikut menyebar dan diaplikasikan dalam kehidupan masyarakat Asia Tenggara. Hasil dari Indianisasi ini antara lain adalah munculnya kekuatan-kekuatan politik berbentuk kerajaan, hadirnya religi baru yang dianut oleh masyarakat Asia Tenggara serta berbagai pengaruh dalam bidang kebudayaan (Coedès, 1975: 14-16). Sebelum proses Indianisasi, sebenarnya telah ada kekuatan politik berbasis kesukuan pada berbagai wilayah di Asia Tenggara, kelompok masyarakat suku inilah yang pasca-Indianisasi melegitimasi kekuasannya dalam bentuk kerajaan seperti yang ada di India. Pengaruh India tidak hanya masuk ke ranah politik melainkan juga ke ranah religi dan berbagai ranah kehidupan lainnya (Hardiati et al., 2010: 30-31). Pada ranah religi, kontak dengan masyarakat Asia Selatan turut membawa pengaruh masuknya agama-agama Asia Selatan yang dalam pembabakan Sejarah Indonesia sering disebut masa Hindu-Buddha, meskipun pada kenyataannya sebelum Hindu Trimurti dan Buddha menjadi agama resmi kerajaankerajaan di Asia Tenggara terdapat religi Weda (Hindu Kuno) yang terlebih dahulu masuk ke Asia Tenggara (Santiko, 2013: 143-144).

Bukti tertulis berupa prasasti menunjukkan kerajaan-kerajaan awal di Asia Tenggara telah berdiri sejak sekitar abad ke-4 sampai 5 Masehi. Bahkan menurut catatan-catatan Bangsa Tionghoa telah ada kerajaan-kerajaan yang berdiri di Asia Tenggara sebelum abad ke-4 Masehi (Liji, 2012: 34-35). Kerajaan-kerajaan di Asia Tenggara yang telah eksis sejak sekitar abad ke-4 sampai 5 Masehi antara lain adalah Kerajaan Kutai Kuno di Kalimantan, Kerajaan Tarumanagara di Jawa Barat. Kerajaankerajaan tertua ini muncul dan berkembang pada kurun waktu yang sama dan berdasarkan tinggalan arkeologisnya menunjukkan karakteristik tinggalan yang serupa, salah satunya adalah arca Wisnu (Coedès, 1975: 34; Dowling, 1999: 54; Hardiati et al.: 34-55, 2010; Havenon, 2006: 84). Berkaitan dengan aspek religi, kerajaan-kerajaan awal ini mengadopsi religi dari India yang tercermin dari isi prasasti, arca, serta sisa bangunan sucinya. Informasi mengenai aspek politik juga menunjukkan pola yang sama, yaitu keberadaan raja-raja bernama India yang memiliki riwayat genealogi dengan sosok pemimpin sebelumnya yang memiliki nama nama non-India (Santiko, 2013: 144).

Berdasarkan hasil penelitian yang telah dilakukan, religi yang dianut oleh rajaraja kerajaan tertua ini adalah Agama Weda (Santiko, 2013: 145; Satari, 2009: 39-40). Agama Weda di Asia Tenggara seperti halnya yang pernah ada di India merupakan pendahulu Agama Hindu. Agama Weda dan Hindu mengagungkan dewa-dewa yang hampir sama, namun dalam posisi dan tingkatan yang berbeda (Stoker, 2007: 171). Agakanya sesuai dengan hasil kajian dari Hariani Santiko (2013: 141-149), pada masa klasik awal di Nusantara pada khususnya dan Asia Tenggara pada umumnya para pemimpin kerajaan menganut agama Weda berasal dari pengaruh India. Keberadaan 
agama Weda di Asia Tenggara dapat ditelusuri dari ritual-ritual persembahan kepada kaum Brahmana yang tercantum dalam prasasti serta informasi pengagungan Wisnu serta tinggalan arca-arca Wisnu pada berbagai situs klasik awal di Asia Tenggara. Perkembangan Agama Weda agaknya berlangsung terus sampai sekitar abad ke-8 Masehi. Menurut telaah terhadap Prasasti Dinoyo menunjukkan penyelenggaraan ritual Weda yang dilakukan oleh Gajayana (Satari, 2009: 39-40). Pasca-abad ke-8, tidak lagi ditemukan bukti keberadaan Agama Weda. Temuan-temuan pasca-abad ke-8 secara umum berkaitan dengan agama Hindu dan Buddha (Hardiati et al. 2010).

Sejalan dengan ketiadaan bukti arkeologi yang berkaitan dengan agama Weda, sejak akhir abad ke-7 telah muncul kekuatan baru yang menggantikan kerajaan-kerajaan tertua. Di Nusantara terdapat Kerajaan Sriwijaya yang berlatar religi Buddha sedangkan di daratan utama Asia Tenggara Kerajaan Chenla dan Dvaravati telah menggantikan Funan. Ketiga kerajaan yang muncul sekitar abad ke-7 ini kesemuanya menganut agama Buddha (Coedès, 1975: 66-82). Hilangnya tinggalan bernapas Weda dan munculnya kekuatan-kekuatan politik baru dalam kurun waktu yang bersamaan menghasilkan permasalahan tentang indikasi terjadinya konversi religi pemimpin-pemimpin politik dari agama Weda (pendahulu Agama Hindu) ke agama Hindu-Buddha. Permasalahan yang muncul selanjutnya berkaitan dengan metode konversi yang dilakukan, apakah dilakukan secara damai atau melalui jalan konflik.

Tulisan ini akan fokus membahas tentang jejak-jejak bencana sosial pada proses konversi religi dan politik di Asia Tenggara pada masa klasik awal serta metode konversi yang dilakukan. Selain membahas tentang tinggalan klasik awal bernapas Weda yang telah disebutkan sebelumnya, tulisan ini juga turut membahas tentang tinggalan-tinggalan bernapas Weda lain yang belum jelas afiliasinya dengan suatu kerajaan. Temuan-temuan tersebut antara lain adalah sisa-sisa struktur dan arca di Kota Kapur, arca Wisnu dari Cibuaya, dan Chaiya, serta temuan koin-koin dari abad ke-5 dari Myanmar (Havenon, 2006: 84; Mitchiner, 1984: 181-185; Santiko, 2013: 148). Tulisan ini dibuat dengan tujuan untuk menghasilkan telaah baru tentang jejak-jejak konversi religi dan politik serta bencana social yang mungkin pernah terjadi. Pembatasan kurun waktu abad ke-5 - ke-7 Masehi didasarkan pada kurun waktu perkembangan kerajaankerajaan tertua yang berakhir pada sekitar abad ke-7 dan khusus di bagain timur Pulau Jawa pada abad ke-8, seiring munculnya tren religi dan politik baru. Diharapkan tulisan ini dapat menjadi salah satu upaya mengungkap satu fase yang dialami bersama oleh masyarakat di kawasan Asia Tenggara.

Data-data penulisan diperoleh melalui metode studi kepustakaan. Studi kepustakaan dilakukan terhadap berbagai sumber antara lain berupa artikel jurnal, buku referensi, serta hasil telaah terhadap catatan Tionghoa yang membahas tentang informasi serta bukti keberadaan kerajaan-kerajaan tertua di Asia Tenggara. Wilayahwilayah yang dibahas pada tulisan ini antara lain adalah Jawa, Kalimantan, Sumatra, dan Daratan Utama Asia Tenggara. Pembahasan akan dibagi menjadi 2 subbab, yaitu yang pertama tentang perkembangan religi-politik di Asia Tenggara Abad ke-5 sampai ke-7 Masehi serta subbab kedua mengenai jejak-jejak bencana sosial yang terjadi pada 
proses konversi religi-politik dari Weda ke Hindu-Buddha di Asia Tenggara. Sesuai dengan definisi dari Badan Nasional Penanggulangan Bencana, bencana sosial merupakan peristiwa konflik sosial antar kelompok atau antar masyarakat yang dalam tulisan ini adalah adalah konflik sosial diakibatkan oleh proses konversi religi dan politik.

\section{HASIL DAN PEMBAHASAN}

\section{Perkembangan Religi-Politik di Asia Tenggara Abad ke-5 sampai 7 Masehi}

Perkembangan religi di Asia Tenggara sejak awal masa sejarah sampai masa modern tidak dapat dilepaskan dari unsur politik. Aspek religi-politik merupakan dua faktor utama yang mendasari kemunculan dan kemunduran dinasti-dinasti di Asia Tenggara selama ribuan tahun. Bukti-bukti urgensi religi-politik dapat terlihat dari polapola kota kuno di Asia Tenggara serta pandangan terhadap sosok raja yang dianggap suci serta diperdewa (Heine-Geldern, 1942: 26). Sosok raja dalam bidang politik dan religi merupakan unsur yang sentral dan memengaruhi berbagai perkembangan religipolitik suatu kerajaan. Pembahasan pada subbab ini akan fokus menelaah bukti-bukti perkembangan religi-politik pada kerajaan-kerajaan tertua di Asia Tenggara.

Pertama, Kerajaan Kutai Kuno diketahui berdasarkan keberadaan 7 (tujuh) prasasti Yupa (Muarakaman) berhuruf Pallawa dan Bahasa Sansekerta di DAS Mahakam. Penemuan prasasti ini menjadi tonggak awal masa sejarah di kepualaun Nusantara. Menurut paleografinya, ketujuh prasasti ini berasal dari abad ke-4 sampai 5 Masehi. Isi dari prasarti-prasasti Yupa tersebut memuat genealogi raja yang pernah memerintah di Kerajaan Kutai (Mardiana et al., 2016: 131-144). Terdapat nama-nama raja yang sudah terpengaruh kebudayaan India, yaitu Aswawarman dan Mulawarman. Selain itu, dicantumkan juga nama raja yang tidak terpengaruh budaya India, yaitu Kundungga. Menurut pendapat para ahli, perubahan nama raja ini disebabkan adanya Indianisasi yang mengubah tradisi politik di Kerajaan Kutai (Hardiati et al., 2010: 3347). Ditinjau berdasarkan aspek religinya, prasasti Yupa (Muarakaman) menginformasikan peristiwa upacara persembahan Raja Mulawarman kepada para Brahmana. Persembahan itu meliputi pemberian hewan ternak dan berbagai macam hasil bumi (Santiko, 2013: 144-145).

Selain temuan berupa Prasasti Yupa, di Kalimantan juga terdapat berbagai temuan struktur bangunan antara lain Candi Laras dan Candi Agung serta arca-arca bernapas Hindu dari Gua Gunung Kombeng (Sedyawati et al., 2014: 184-194). Berdasarkan temuan-temuan yang ada di Pulau Kalimantan dapat diketahui bahwa Indianisasi berlangsung sejak sekitar abad ke-4 sampai 5 masehi dan terus berlanjut pada masa yang lebih kemudian. Temuan di Pulau Kalimantan sangat minim unsur pertanggalan, namun berdasarkan analisis carbon dating didapatkan kurun waktu penggunaan situs-situs klasik sampai dengan abad ke-14 (Sedyawati et al., 2014: 193). Apabila dihubungkan periodisasi aspek religi terlihat bahwa pada mulanya terdapat tinggalan bernapas Weda dan pada masa yang lebih kemudian temuan didominasi dengan napas Hindu. 
Kedua, Kerajaan Tarumanagara berdasarkan penanggalan relatif pada prasastiprasastinya, diperkirakan eksis pada abad ke-5 Masehi (Hardiati et al., 2010: 48). Prasasti Ciaruteun yang ditemukan di Kampung Muara, Bogor juga memberikan informasi tentang sosok Raja Purnawarman yang telapak kakinya terpahat pada prasasti. Telapak kaki tersebut juga diidentikan dengan telapak kaki Dewa Wisnu. Selain itu, keberadaan Prasasti Kebun Kopi yang menampilkan pahatan telapak kaki gajah Airawata yang merupakan wahana Dewa Indra turut memberikan petunjuk tentang pemujaan terhadap Dewa Indra (Santiko, 2001: 423-426). Adanya praktik pemujaan terhadap Dewa Wisnu dan Indra dapat dikaitkan dengan praktik religi Weda. Di India para penganut Weda juga memfokuskan praktik religinya pada Indra, Wisnu, dan Agni yang kemudian pada saat ajaran Hindu menggantikan Weda, Wisnu tetap menjadi satu dari tiga dewa utama (Khaire, 2003: 168). Dikaitkan dengan aspek politik, penyebutan sosok Raja Purnawarman yang diindentikkan dengan Dewa Wisnu dalam prasasti menunjukkan posisinya sebagai raja sekaligus titisan dewa.

Selain prasasti-prasasti dari masa Tarumanagara, di bagian barat Pulau Jawa juga ditemukan dua arca Wisnu dari Cibuaya yang berdasarkan gayanya serupa dengan yang ditemukan di Kota Kapur, Kamboja, dan Chaiya. Mengenai afiliasi arca Wisnu ini terdapat pendapat yang menghubungkannya dengan Tarumanagara dan Percandian Batujaya (Hardiati et al., 2010: 48). Apabila ditinjau dari segi religi dan kronologi, arca Wisnu Cibuaya lebih dekat dengan Tarumanagara dibandingkan Batujaya. Hal ini didasarkan perbedaan religi, yang menunjukkan bahwa percandian Batujaya menurut hasil penelitian Hasan Djafar (2007: 226) merupakan percandian bernapas Buddha namun tidak menutup kemungkinan penguasa Batujaya merupakan kelanjutan dari penguasa Tarumanagara pasca konversi religi-politik. Pada wilayah yang sekarang bernama Banten juga terdapat tinggalan klasik berupa Situs Banten Girang. Temuan di situs Banten Girang antara lain berupa arca-arca Hindu-Saiwa. Menurut penanggalan relatif, arca-arca ini kemungkinan berasal dari abad ke-10 (Guillot, 2008: 18-20). Keberadaan situs-situs non-Buddha ini sesuai dengan informasi Fa-Hsien yang dalam catatannya menyebutkan mayoritas penduduk di bagian barat Pulau Jawa tidak menganut Agama Buddha (Liji, 2012: 34). Informasi tentang keberadaan situs-situs Hindu-Buddha dengan kronologi lebih muda di bagian barat Pulau Jawa menunjukkan pola yang sama dengan yang ada di Pulau Kalimantan, yaitu terjadinya konversi religipolitik dari penguasa Weda kepada penggantinya, penguasa Hindu-Buddha.

Ketiga, di bagian timur Pulau Jawa pada abad ke-8 telah ada Kerajaan Kanjuruhan. Informasi tentang Kerajaan Kanjuruhan dapat diketahui melalui Prasasti Dinoyo yang ada di Malang (Brandes, 1913: 1). Prasasti Dinoyo menyebutkan keberadaan sosok pemimpin bernama Gajayana yang melaksanakan upacara keagamaan berkaitan dengan Agastya dan Lingga. Ritual keagamaan Weda ini dapat dibuktikan dengan adanya pengistimewaan Agastya, upacara kurban, dan caru yang sangat sesuai dengan Upacara Somayajna dalam agama Weda. Setelah kurun waktu abad ke-8 Masehi belum ada bukti pelaksanaan praktik Weda yang dapat ditelusuri. 
Keempat, di Pulau Bangka juga pernah ditemukan Arca Wisnu, fragmen lingga, dan struktur bangunan dari batu kapur dari Situs Kota Kapur. Arca Wisnu yang ditemukan di Kota Kapur secara ikonografis memiliki kesamaan dengan arca-arca Wisnu lain seperti yang telah disebutkan di atas. Temuan arca dan fragmen lingga menunjukkan adanya praktek religi Weda yang pernah ada di Situs Kota Kapur (Santiko, 2013: 147-148). Selain temuan-temuan yang telah disebutkan sebelumnya, di Situs Kota Kapur juga ada prasasti kutukan dari Kerajaan Sriwijaya yang berlatar religi Buddha dari abad ke-7 yang berasal dari Sriwijaya. Prasasti Kota Kapur, seperti halnya prasasti-prasasti Sriwijaya awal lainnya berisi tentang kutukan bagi pihak yang tidak tunduk pada Sriwijaya, artinya ada kecenderungan upaya untuk mempertahankan wilayah yang telah ditaklukkan (Izza, 2019: 114-115; Mardiana et al., 2016: 59-61). Antara temuan prasasti dan temuan-temuan lain di Kota Kapur memiliki latar religi yang berbeda. Isi prasasti Kota Kapur memiliki latar religi Buddha sedangkan temuantemuan lain berkaitan erat dengan agama Weda. Penelitian terkini dari Situs Kota Kapur menunjukkan keberadaan sisa-sisa dermaga yang menurut analisis carbon dating berasal dari abad ke-5 (Indrajaja \& Siregar, 2016: 24). Apabila dibandingkan dengan penanggalan prasasti wilayah Kota Kapur telah menjadi tempat kegiatan manusia sejak masa pra-Sriwijaya.

Kelima, di daratan utama Asia Tenggara tepatnya di Delta Mekong terdapat situs perdagangan kuno yaitu Oc-Eo. Di sekitar Oc-Eo inilah terdapat bukti-bukti adanya kerajaan pra-Angkor. Temuan-temuan klasik ini tersebar di Provinsi Takeo, Kamboja yang terletak dekat dengan perbatasan Vietnam. Di Bukit Phnom Da ditemukan candi, gua, dan arca-arca Wisnu berukuran manusia (Dowling, 1999: 54). Ditinjau berdasarkan ukurannya, arca-arca Wisnu dari Kamboja memiliki ukuran lebih besar dari arca Wisnu lain dari kurun waktu yang sama. Kajian sejarah pra-Angkor menunjukkan keberadaan Kerajaan Funan yang eksis sejak awal abad Masehi sampai dengan abad ke-7 Masehi. Informasi tentang Kerajaan Funan dapat ditemui dari catatan Bangsa Tionghoa yang menyebut keberadaan Funan yang dipimpin oleh seorang wanita bernama Liu-yie bersama orang India bernama Kaundinya, sebelum akhirnya ditakhlukan Chenla yang menganut Buddha sekitar abad ke-7 Masehi (Vickery, 2003: 115-129). Berdasarkan informasi tentang keadaan religi dan politik Kerajaan Funan dan Chenla agaknya fase perkembangan dan hilangnya pengaruh Weda serta munculnya kerajaan-kerajaan penerus di Nusantara dan Kamboja-Vietnam memiliki pola dan kurun waktu yang hampir sama.

Keenam, di Chaiya, Thailand pernah ditemukan arca Wisnu yang juga memiliki gaya yang sangat mirip dengan arca wisnu dari Cibuaya. Arca ini terletak di Wat Sala Tung dan diperkirakan berasal dari akhir abad ke-6. Menurut Havenon (2006: 84) kuat indikasi arca ini berkaitan dengan tradisi India klasik atau dalam kata lain Weda. Apabila dikaitkan dengan posisinya dalam jalur perdagangan pada masa klasik, Chaiya merupakan salah satu lokasi yang strategis. Bahkan pada masa yang lebih kemudian, yaitu sekitar abad ke-7 - 12 Masehi pernah dikuasai oleh Sriwijaya yang menunjukkan tinggalan-tinggalan bernapas Buddha (De Casparis, 1967: 31 \& 39) . 
Ketujuh, di Myanmar (Burma) juga ditemukan koin-koin kuno yang diperkirakan berasal dari sekitar abad ke-5 sampai 6 Masehi atau masa pra-Burma ketika pengaruh Buddha belum masuk ke Myanmar. Beberapa koin-koin tersebut ditemukan di lokasi Pagoda Bawbawgyi, yaitu pagoda Buddha tertua di Myanmar, sedangkan koin-koin lainnya tidak diketahui berasal dari mana. Koin-koin tersebut memiliki simbol-simbol yang tidak ditemukan pada koin-koin dari masa yang lebih kemudian. Simbol-simbol tersebut antara lain berbentuk mirip dengan Yupa (Mitchiner 1984). Keberadaan koin-koin dengan simbol unik ini mengindikasikan adanya masyarakat yang menganut latar religi Weda di Myanmar sezaman dengan perkembangan kerajaan-kerajaan awal di Nusantara dan Kamboja.

Ketujuh poin pembahasan di atas menunjukkan proses Indianisasi yang berlangsung pada kurun waktu yang bersamaan pada berbagai wilayah di Asia tenggara. Lebih lanjut, bukti-bukti awal Indianisasi di Asia Tenggara juga menunjukkan adanya persebaran penganut Agama Weda di Asia Tenggara. Selain itu, prasasti-prasasti yang berkaitan dengan kekuasaan politik juga menunjukkan kerajaan-kerajaan tertua di Asia Tenggara memperkuat posisi Agama Weda sebagai kepercayaan resmi yang dianut oleh kerajaan. Pembahasan yang telah dilakukan juga menunjukkan fenomena konversi religi dari Weda ke Hindu-Buddha yang terjadi dalam kurun waktu yang bersamaan dengan konversi politik di Asia Tenggara. Proses konversi ini umumnya berlangsung sekitar abad ke-7 Masehi.

\section{Jejak-jejak Bencana Sosial Pada Proses Konversi Religi-Politik dari Weda ke Hindu-Buddha}

Pada subbab sebelumnya telah dijabarkan tentang proses perkembangan religi dan politik pada masa klasik awal di Asia Tenggara. Di antara proses konversi dari Weda ke Hindu-Buddha terdapat jejak-jejak adanya konflik sosial pada beberapa wilayah. Istilah konflik sosial dalam subbab ini selanjutnya akan disebut sebagai bencana sosial. Pada enam bukti keberadaan agama Weda di Asia Tenggara, setidaknya ada dua proses konversi yang memuat jejak-jejak bencana sosial, yaitu proses konversi religi-politik yang terjadi di Pulau Bangka dan Kerajaan Funan. Mengenai bukti-bukti lain, sesuai dengan penjabaran pada subbab sebelumnya menunjukkan adanya koversi, namun mengenai bukti-bukti bencana sosial yang mengiringi prosenya belum dapat ditemukan bukti-buktinya hingga kini, namun ada dugaan-dugaan tentang keterkaitan penyerangan yang terjadi di satu wilayah dengan wilayah lainnya.

Prasasti Kota Kapur memberikan informasi tentang keberadaan Kerajaan Sriwijaya yang mengeluarkan ancaman kutukan kepada musuh-musuh yang ingin mengganggu kedaulatannya. Informasi tentang musuh Sriwijaya ini memberikan informasi tentang keberadaan kerajaan lain yang sezaman atau lebih tua dari Sriwijaya (Mardiana et al., 2016: 59-62). Melihat persebaran dan kekhasan isi prasasti-prasasti tertua Sriwijaya, agaknya pada akhir abad ke-7 Sriwijaya memang sedang gencar menyerang berbagai lokasi yang ingin dikuasai (Izza, 2019: 111-122). Keberadaan Prasasti Kota Kapur sekaligus menunjukkan adanya penaklukan terhadap kekuatan 
politik yang telah ada sebelumnya, Berdasarkan adanya perbedaan latar religi antara prasasti dan temuan-temuan lain di Situs Kota Kapur mengindikasikan adanya peristiwa penaklukan yang terjadi antara masyarakat beragama Weda di Pulau Bangka dengan Sriwijaya sebagai kerajaan berlatar Buddha yang sedang meluaskan wilayahnya. Mengenai latar belakang penaklukan ini selain faktor religi, juga dapat dihubungkan dengan faktor ekonomi. Pulau Bangka secara geografis memiliki posisi strategis dalam perdagangan. Selain itu, keberadaan sisa-sisa dermaga kuno juga menunjukkan adanya aktivitas pelayaran Pulau Bangka bahkan sebelum masa Sriwijaya. Selain dalam bidang perdagangan, alam Pulau Bangka juga menyediakan sumber daya alam yang penting. Ketersediaan timah di Pulau Bangka juga berfungsi sebagai salah satu sumber ekonomi (Utomo, 2014: 6-7). Melihat posisi dan potensi ekonomi inilah yang diindikasikan menjadi faktor pendorong utama penaklukan politik dan religi di Pulau Bangka.

Selain informasi tentang kutukan, pada Prasasti Kota Kapur juga terdapat informasi tentang pasukan yang berangkat menyerang Bhumi Jawa (Mardiana et al., 2016: 59-62). Letak Bhumi Jawa dalam Prasasti Kota Kapur masih menjadi perdebatan. Sebagian ahli berpendapat bahwa Bhumi Jawa yang dimaksud terletak di Lampung tempat prasasti-prasasti kutukan serupa diletakkan, sedangkan ahli-ahli lain berpendapat Bhumi Jawa yang dimaksud adalah kekuatan politik (kerajaan) lain yang ada di Pulau Jawa (Boechari, 1979: 25; Coedès, 1975: 83). Dihubungkan dengan kekuatan politik yang eksis di Pulau Jawa pada masa itu terdapat Kerajaan Tarumanagara yang berdasarkan periodisasinya lenyap sekitar akhir abad ke-7, masuk akal kiranya pendapat dari Coedès jika nama Bhumi Jawa yang dimaksud oleh Sriwijaya sebenarnya adalah Tarumanagara. Lebih jauh lagi menurut Claude Guillot (2008: 18-20) terdapat kerajaan lain selain Banten Girang di bagian barat Pulau Jawa yang didirikan kembali pada 932 di bawah Sriwijaya, hal ini memperkuat dugaan tentang daerah Bhumi Jawa dan bencana sosial yang pernah terjadi akibat serangan Sriwijaya pada abad ke-7. Selain di wilayah yang disebut Bhumi Jawa, sesuai dengan keterangan sebelumnya, Sriwijaya pada masa lalu juga menguasai daerah Thailand, yaitu daerah Chaiya. Keberadaan Arca Wisnu di Kota Kapur dan Chaiya yang sangat mirip memperkuat dugaan adanya proses penaklukan Sriwijaya ke lokasi-lokasi strategis di Asia Tenggara.

Jejak-jejak bencana sosial pada proses konversi religi dan politik pada sekitar akhir abad ke-6 sampai ke-7 Masehi juga ditemukan di Kamboja pada masa akhir Funan sampai dengan pengambilalihan kekuasaan oleh Chenla. Menurut sejarah Kamboja, disebutkan dalam Catatan Tionghoa, Chenla pernah menjadi vasal Kerajaan Funan. Pada masa akhir Funan seiring dengan melemahnya kekuasaan dan bersamaan masuknya Agama Buddha ke Kamboja muncul kekuatan religi dan politik baru. Ketika Chenla mulai kuat akibat menguasai jalur perdagangan, maka Chenla berusaha mengambil kekuasaan Funan, peristiwa ini merupakan konflik sosial menandai perubahan mendasar dalam bidang religi dan politik. Kehancuran Funan sekaligus menandai masuknya masa Khmer (Vickery, 2003: 103). Sebenarnya faktor religi bukan menjadi satu-satunya dasar terjadinya bencana sosial, faktor utama lainnya yang mendasari bencana sosial adalah masalah penguasaan daerah dan pusat perdagangan 
yang sebelumnya dikuasai Funan. Pada kasus Funan-Chenla dapat dipahami sebagai usaha merebut pusat-pusat dagang strategis. Di sisi lain pada kurun waktu tersebut sedang muncul pengaruh religi baru dari India yang menggantikan Weda yang mendorong munculnya penguasa-penguasa baru yang merasa berhak melakukan ekspansi ke daerah lain.

Informasi serta data tentang jejak-jejak bencana sosial pada proses konversi religi-politik di situs lain sangatlah minim, sehingga belum dapat diketahui secara pasti apakah proses konversi religi-politik tersebut diwarnai dengan konflik sosial atau berlangsung secara damai. Di Kalimantan, bagian timur Pulau Jawa, Thailand, dan Myanmar misalnya, bukti-bukti yang ada menunjukkan adanya fenomena konversi religi-politik, namun jejak-jejak konflik atau bencana sosialnya belum dapat ditelusuri. Terbuka kemungkinan proses konversi religi-politik pada sebagain wilayah di Asia Tenggara berlangsung secara damai. Apabila dibandingkan dengan masa yang lebih kemudian, negeri-negeri di Asia Tenggara juga mengalami berbagai fase konversi religi-politik. Antara lain adalah proses konversi religi-politik dari masa klasik ke masa Islam di Semenanjung Melayu dan Nusantara serta revolusi yang terjadi sepanjang masa penjajahan sampai kemerdekaan negeri-negeri Asia Tenggara. Berbagai proses konversi tersebut ada yang berlangsung secara damai, misalnya proses Islamisasi di Semenanjung Melayu dan Nusantara yang umumnya berlangsung secara bertahap dan damai (Tjandrasasmita, Manus, Lapian, \& Ambary, 2009: 13). Selain itu, ada juga yang terjadi melalui bencana sosial berupa perang dan pengambilalihan kekuasaan secara paksa, misalnya peristiwa perebutan kedaulatan raja-raja di Asia Tenggara ke tangan penjajah dan perebutan kemerdekaan dari Bangsa-bangsa Eropa (Cotterell 2014).

\section{SIMPULAN}

Pembahasan pada tulisan ini menunjukkan munculnya kerajaan-kerajaan tertua yang telah terpengaruh Indianisasi terjadi sekitar abad ke-5 masehi. Bukti-bukti arkeologis dan epigrafis menunjukkan pada mulanya kerajaan-kerajaan tertua ini menganut Agama Weda dan pada sekitar abad ke-7 Masehi terjadi konversi religi dari Weda ke Hindu-Buddha. Konversi religi berlangsung bersamaan dengan konversi politik yang juga dilatarbelakangi oleh faktor ekonomi. Di antara situs-situs di Asia Tenggara, jejak bencana sosial yang mewarnai proses konversi religi-politik dapat ditelusuri dari tinggalan yang ada di Pulau Bangka dan catatan tentang upaya pendudukan Funan oleh Chenla di Kamboja. Peristiwa-peristiwa yang telah dijelaskan di atas menunjukkan keseragaman pola perkembangan religi dan ekonomi di Asia Tenggara pada sekitar abad ke-5 - 7 Masehi. Untuk itu, perlu dilakukan kajian lebih mendalam tentang eratnya hubungan antara negeri-negeri di Asia Tenggara khususnya pada masa eksisnya pengaruh Indianisasi (Masa Klasik). 


\section{DAFTAR PUSTAKA}

Boechari, M. 1979. "An Old Malay Inscription of Sriwijaya at Palas Pasemah (South Lampung).” In Pra Seminar Penelitian Sriwijaya, 19-42. Jakarta: Pusat Penelitian Arkeologi Nasional.

Brandes, J.L.A. 1913. Oud-Javaansche Oorkonden: Nagelaten Transscripties. Batavia: Albrecht \& Co.

Casparis, J. G. De. 1967. “The Date of the Grahi Buddha.” Journal Social Science 55 (1): $31-40$.

Coedès, George. 1975. The Indianized States of Southeast Asia. Diedit oleh Walter F. Vella. Canberra: Australian National University Press.

Cotterell, Arthur. 2014. A History of Southeast Asia. Singapore: Marshall Cavendish Editions.

Djafar, Hasan. 2007. "Kompleks Percandian di Kawasan Situs Batujaya, Karawang, Jawa Barat: Kajian Sejarah Kebudayaan." Universitas Indonesia.

Dowling, Nancy H. 1999. "A New Date for the Phnom Da Images and Its Omplications for early Cambodia." Asian Perspectives 38 (1): 51-61.

Guillot, Claude. 2008. Banten: Sejarah dan Peradaban Abad X-XVII. Jakarta: Kepustakaan Populer Gramedia.

Hardiati, E.S, H Djafar, Soeroso, P.E.J Ferdinandus, dan T.S Nastiti. 2010. Sejarah Nasional Indonesia Jilid II: Zaman Kuno. Jakarta: Balai Pustaka.

Havenon, Michael D. 2006. "The Earliest Viṣnu Sculpture from Southeast Asia.” The Journal of the Walters Art Museum 64: 81-98.

Heine-Geldern, Robert. 1942. "Conceptions of State and Kingship in Southeast Asia." The Far Easter Quarterly 2 (1): 15-30.

Indrajaja, Agustijanto, dan Darwin A. Siregar. 2016. "Dermaga Kuna di Situs Kota Kapur dan Analisis Pertanggalan Absolut.” Kalpataru 25 (1): 15-28.

Izza, Nainunis Aulia. 2019. "Prasasti-prasasti Sapatha Sriwijaya: Kajian Panoptisisme Foucault." Titian: Jurnal Ilmu Humaniora 3 (1): 110-23.

Khaire, Vishvanatrh. 2003. "Visnu In The Veda." Annals of The Bhandarkar Oriental Research Institute 84: 163-69.

Liji, Liang. 2012. Dari Relasi Upeti ke Mitra Strategis: 2.000 Tahun Perjalanan Hubungan Tiongkok-Indonesia. Jakarta: Penerbit Buku Kompas.

Mardiana, Intan, Trigangga, Hasan Djafar, Ninie Susanti Tedjowasono, Andriyati Rahayu, dan Fifia Wardhani. 2016. Prasasti Batu I: Pembacaan Ulang dan Alih Aksara. Jakarta: Museum Nasional Indonesia.

Mitchiner, Michael. 1984. "The Cosmological Scene Depicted on Some Early Burmese Symbolic Coins." East and West 34 (1): 175-88.

Santiko, Hariani. 2001. "The Religion of King Purnawarman of Tarumanagara.” In Fruits pf Inspiration: Studies in Honour if Prof. J. G. De Casparis, 566. Groningen: Egbert Forsten.

_. 2013. "The Vedic Religion in Nusantara." Amerta: Jurnal Penelitian dan Pengembangan Arkeologi 31 (2): 141-49.

Satari, Sri Soejatmi. 2009. "Upacara Weda di Jawa Timur: Telaah Baru Prasasti Dinoyo.” Amerta: Jurnal Penelitian dan Pengembangan Arkeologi 27 (1): 3443.

Sedyawati, Edi, Hariani Santiko, Hasan Djafar, Ratnaesih Maulana, Wiwin Djuwita Sudjana Ramelan, Edhie Wurjantoro, dan Bambang Budi Utomo. 2014. Candi Indonesia II: Seri Sumatera, Bali, Kalimantan, Sumbawa. Jakarta: Direktorat 
Pelestarian Cagar Budaya dan Permuseuman, Direktorat Jenderal Kebudayaan, Kementerian Pendidikan dan Kebudayaan.

Stoker, Valerie. 2007. "Vedic Language and Vaisnava Theology: Madhva's Use of

Nurukta in His Rgbhasya." Journal of Indian Philosophy 35 (2): 169-99.

Tjandrasasmita, Uka, M. P. B Manus, A. B Lapian, dan Hasan Muarif Ambary. 2008.

Sejarah Nasional Indonesia III: Zaman Pertumbuhan dan Perkembangan

Kerajaan Islam di Indonesia. Jakarta: Balai Pustaka.

Utomo, Bambang Budi. 2014. "Bangka-Belitung dalam Lintas Niaga." Buletin Relik, 2014.

Vickery, Michael. 2003. "Funan Reviewed: Deconstructing the Ancients." Bulletin de l'Ecole française d'Extrême-Orient 90: 101-43.

\section{HASIL DISKUSI}

\section{Pertanyaan}

1. Dian Diana (SMP Negeri 1 Cihampelas)

Apakah Kompleks Muaro Jambi termasuk ke dalam candi yang mengalami konversi religi dari Weda ke Hindu Buddha dan bisakah berikan sedikit penjelasan mengenai kompleks percandian tersebut?

\section{Jawaban}

1. Pembahasan dalam makalah kali ini memang tidak membahas Candi Muaro Jambi karena memang tidak ada data yang menyebutkan konversi religi dari Weda ke Hindu Buddha maupun tentang adanya bencana sosial yang diakibatkan dari konversi tersebut. Percandian Muaro Jambi sendiri memang merupakan salah satu kawasan percandian Buddha terluas di Asia Tenggara. Ada temuan arca Nandi dan arca Wisnu. 